\title{
ANALISIS COMMON-SIZE UNTUK MENILAI KINERJA KEUANGAN PERUSAHAAN PADA PT INDOSAT TBK. DAN PT TELKOMUNIKASI TBK. (Tahun 2014-2016)
}

\author{
Mohammad Harisudin Z; Gandung Satriyono; Nursamsu \\ Fakultas Ekonomi - Universitas Kadiri \\ E-mail : gandungsatriyono@unik-kediri.ac.id
}

\begin{abstract}
This study aims to determine the financial performance using common size in PT Indosat, Tbk. and PT Telekomunikasi, Tbk. which are listed in Indonesia stock Exchange during the years 2014-2016 review of balance sheet and income statement. This research is quantitative descriptive research. Data were collected by the method of documentation and analysis of the data used is the percentage per component analysis or common size. The results showed that the common size terms of balance sheet, of PT Indosat, Tbk. which allocates funds to assets the majority of the debt PT Telecom, Tbk. allocate funds for the assets of their own capital thereby increasing the margin of safety for creditors and strengthen the financial position of the company. Common size observed from the income statement, PT Indosat, Tbk. and PT Telekomunikasi, Tbk.experienced an increase in net income in the year of 2016 so that the company's financial performance is getting better and 2014-2015 financial performance is less good because of the decline in net income.
\end{abstract}

Keywords: common size, financial performance, income statement, balance sheet.

\begin{abstract}
ABSTRAK
Penelitian ini bertujuan untuk mengetahui kinerja keuangan dengan menggunakan common size pada perusahaan PT Indosat, Tbk. dan PT Telekomunikasi, Tbk. yang terdaftar di Bursa Efek Indonesia selama tahun 2014-2016 ditinjau dari neraca dan laporan laba rugi. Penelitian ini merupakan penelitian deskriptif kuantitatif. Data dikumpulkan dengan metode dokumentasi dan analisis data yang digunakan yaitu analisis persentase per komponen atau common size. Hasil penelitian menunjukkan bahwa common size ditinjau dari neraca, PT Indosat, Tbk. yang mengalokasikan dana untuk aktiva sebagian besar dari utang PT Telekomunikasi, Tbk. mengalokasikan dana untuk aktiva dari modal sendiri sehingga meningkatkan margin of safety bagi kreditur dan menguatkan posisi keuangan perusahaan. Common size ditinjau dari laporan laba rugi, PT Indosat, Tbk. dan PT Telekomunikasi, Tbk.mengalami peningkatan pada laba bersihnya pada tahun 2016 sehingga kinerja keuangan perusahaan semakin baik dan tahun 2014-2015 kinerja keuangan kurang baik karena mengalami penurunan pada laba bersihnya.
\end{abstract}

Kata kunci: common size, kinerja keuangan, laporan laba rugi, neraca. 


\section{PENDAHULUAN}

\section{Latar Belakang}

Perusahaan telekomunikasi termasuk kedalam perusahaan yang memiliki pergerakan dinamis, dimana penggunanya meningkat setiap tahunnya dengan jumlah operator dan jenis layanan yang ditawarkan juga bervariasi (kompas.com diakses pada rabu, 10 Juni 2016). Menurut data dari kompas.com Indonesia memiliki perusahaan telekomunikasi yang cukup besar yaitu telkomsel, indosat, XL axiata, smartFren, dan juga bakrie Telkom.

Menurut data yang dikeluarkan oleh dirjen postel periode 2014-2016 pertumbuhan rata-rata pengguna ponsel menunjukkan 45,6\% pertahun, dengan pesatnya pertumbuhan pengguna ponsel ini maka investor tertarik untuk melakukan investasi pada perusahaan yang dinilai memberikan keuntungan kepada investor dan pemegang saham.

Laporan keuangan adalah catatan pelaporan keuangaan perusahaan dalam jangka waktu yang ditentukan dan memiliki fungsi sebagai control kinerja perusahaan yang nantinya digunakan oleh manajemen untuk pengambilan keputusan (Keown, 2011). Data yang tercantum pada laporan keuangan digunakan oleh pihak-pihak yang memiliki kepentingan, terutama investor dan pemegang saham untuk pedoman dalam pengambilan keputusan, hal ini menunjukkan bahwa dalam laporan keuangan dapat diketahui secara akurat tentang kinerjea sebuah perusahaan (Putra \& Laely, 2015) yang nantinya akan adapat digunakan sebagai dasar analisis kinerja keuangan (Sundjaja et al, 2003).

Analisis laporan keuangan digunakan untuk mengetahui besar tingkat risiko, tingkat kesehatan dan tingkat keuntungan sebuah perusahaan. Dimana tujuan utama dari analisis laporan keuangan untuk mengurangi permasalahan dalam pengambil keputusan dan menghindari pengambilan keputusan pada ketidakpastian (Suhayati et al, 2009).

Dalam menggunakan laporan keuangan sebagai dasar analisis, dapat menggunakan analisis Common-size, yaitu sebuah metode proses penghitungan dengan menggunakan perbandingan setiap pos yang ada pada neraca dan laporan laba rugi, dimana menggunakan penjualan bersih untuk perhitungan laba rugi dan perhitungan total kekayaan untuk neraca ( Hanafi et al, 2009).

Penelitian Prihastuti et al (2017) Analisis Kinerja Keuangan Dengan Menggunakan Common Size Pada Perusahaan Otomotif Yang Terdaftar Di Bursa Efek Indonesia (BEI) Tahun 2016 menunjukkan Kinerja keuangan dengan menggunakan Common size pada perusahaan otomotif yang terdaftar di BEI tahun 2016 ditinjau dari 
neraca, perusahaan mengalokasikan dana untuk aktiva semakin menurun,sedangkan ditinjau dari laporan laba rugi mengalami peningkatan untuk menghasilkan laba bersih (Vaulia, 2017).

Binti (2015) dalam penelitiannya menggunakan Analisis Common Size Untuk Membandingkan Kinerja Keuangan Perusahaan Pada Kelompok Perusahaan Telekomunikasi yang Terdaftar Di Bursa Efek Indonesia ( BEI ) Tahun 2010 - 2014 diperoleh kesimpulan bahwa PT. Telkom memiliki kinerja keuangan perusahaan yang cukup baik. Jika dilihat di dalam neraca common size, perusahaan sudah mampu menjaga tingkat kestabilan hutangnya.

\section{Rumusan Masalah}

Rumusan masalah penelitian ini adalah bagaimanakah kinerja keuangan perusahaan PT Indosat, Tbk. dan PT Telkomunikasi, Tbk. diukur menggunakan analisis Common-size selama tahun 2014-2016?

\section{Tujuan Penelitian}

tujuan penelitian ini yaitu untuk mengetahui kinerja keuangan melalui rasiorasio yang dianalisis menggunakan Common-size pada PT Indosat, Tbk. dan PT Telkomunikasi, Tbk selama tahun 2014-2016.

\section{TINJAUAN PUSTAKA}

\section{Landasan Teori}

\section{Laporan Keuangan}

Harahap (2013), menyatakan bahwa laporan keuangan bermaksud memberikan informasi mengenai kondisi keuangan perusahaan. Laporan keuangan menggambarkan kondisi keuangan dan hasil usaha suatu perusahaan pada saat tertentu atau jangka waktu tertentu.

\section{Komponen-komponen Laporan Keuangan}

Laporan keuangan yang lengkap dapat dilihat dalam PSAK No. 1 (2002) yang terdiri dari komponen-komponen berikut ini :

a. Neraca

Laporan posisi keuangan adalah suatu laporan sistematis tentang aset, pasiva, dan ekuitas.

b. Laporan Laba Rugi

Laporan yang menyajikan seluruh pos pendapatan dan beban yang diakui satu periode. 
c. Laporan perubahan ekuitas

Ikhtisar tentang perubahan modal suatu perusahaan yang terjadi selama jangka waktu tertentu.

d. Laporan arus kas

Laporan yang menyajikan laporan yang relevan tentang penerimaan dan pengeluaran kas yang berasal dari kegiatan investasi, pembelanjaan, dan kegiatan usaha lainnya.

\section{Analisis Laporan Keuangan}

Harahap (2013), menyatakan analisis laporan keuangan adalah menguraikan pospos laporan keuangan menjadi unit informasi yang lebih kecil dan melihat hubungannya yang bersifat signifikan atau yang mempunyai makna antara satu dengan yang lain baik antara data kuantitatif maupun data non-kuantitaif dengan tujuan untuk mengetahui kondisi keuangan lebih dalam yang sangat penting dalam proses menghasilkan keputusan yang tepat.

\section{Analisis Common-size}

Hanafi et al ( 2009), menyatakan analisis Common-size merupakan teknik analisis yang membuat perbandingan dan menghitung tiap-tiap rekening dalam laporan laba-rugi dan neraca menjadi proporsi dari total penjualan untuk laporan laba rugi atau dari total aset untuk neraca.

\section{Kinerja Keuangan}

Sawir (2005),menyatakan kinerja keuangan adalah penentuan ukuran-ukuran tertentu yang dapat mengukur keberhasilan suatu organisasi atau perusahaan dalam menghasilkan laba. Kinerja keuangan dapat diukur dengan menganalisa dan mengevaluasi laporan keuangan. Informasi posisi keuangan dari kinerja keuangan di masa lalu sering kali digunakan sebagai dasar untuk memprediksi posisi keuangan dan kinerja perusahaan di masa depan dan hal-hal yang langsung menarik perhatian pemakai seperti pembayaran dividen, upah, pergerakan harga, sekuritas dan kemampuan perusahaan untuk memenuhi komitmennya ketika jatuh tempo (IkatanAkutansi Indonesia, 2002).

\section{Kerangka Berpikir}

Sugiyono (2010), menyatakan kerangka berpikir merupakan model konseptual tentang bagaimana teori berhubungan dengan berbagai faktor yang telah diidentifikasi sebagai masalah yang penting 


\section{Gambar 1 Kerangka Berpikir}

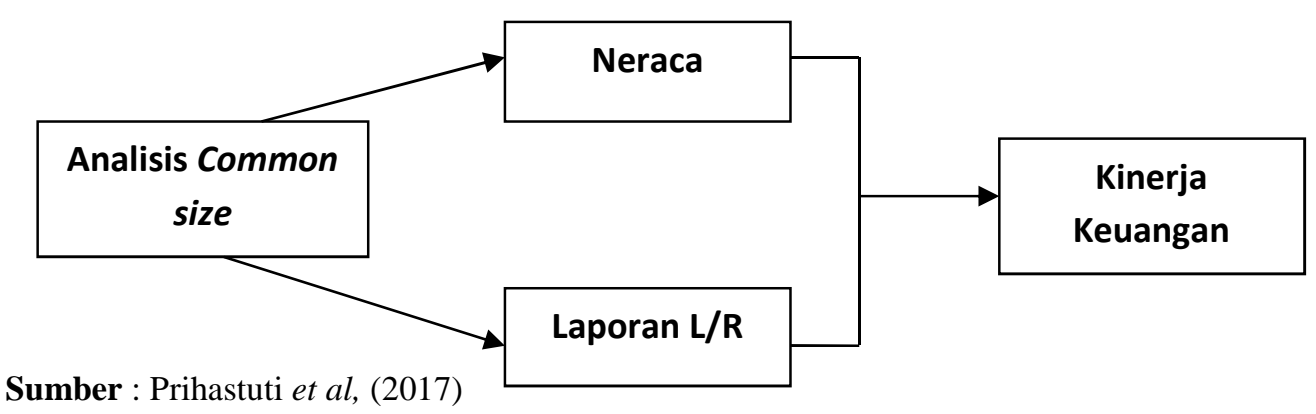

\section{METODE PENELITIAN}

\section{Populasi dan Sampel Penelitian}

Populasi adalah wilayah generalisasi yang terdiri atas obyek/subyek yang mempunyai kualitas dan karakteristk tertentu yang ditetapkan oleh peneliti untuk dipelajari dan kemudian ditarik kesimpulannya (Sugiyono, 2006).

Sampel adalah bagian dari jumlah dan karakteristik yang dimiliki oleh populasi tersebut (Sugiyono, 2006). Sampel penelitian ini adalah PT Indosat, Tbk. dan PT Telkomunikasi, Tbk.

\section{Variabel Peneltian}

\section{Variabel Independent (X)}

Variabel independen atau bebassering disebut sebagai variabel stimulus, predictor, antecedent adalah variabel yang mempengaruhi atau yang menjadi sebab perubahannya atau timbulnya variabel dependen (terikat) (sugiyono,2012), yang menjadi variable bebas dalam penelitian ini adalah analisis Common-size (X). Analisis Common-size yang terdiri dari :

1. Neraca (X1.1)

Suatu laporan sistematis tentang aktiva, pasiva, dan ekuitas.

2. Laporan laba-rugi (X1.2)

Laporan yang menyajikan seluruh pos pendapatan dan beban yang diakui satu periode.

\section{Variabel Dependent (Y)}

Variabel dependen atau terikat sering disebut variable output, kriteria, konsekuen adalah variabel yang dipengaruhi atau yang menjadi akibat, karena adanya variable bebas (Sugiyono,2012), maka yang menjadi variable terikat dalam penelitian ini adalah kinerja keuangan (Y). 


\section{Metode Pengumpulan Data}

Teknik pengumpulan data yang dilakukan dalam penelitian ini adalah dokumentasi. Dokumentasi dalam penelitian ini digunakan untuk mengumpulkan data laporan keuangan tahunan perusahaan PT Indosat, Tbk. dan PT Telkomunikasi, Tbk. tahun 2014-2016 berupa neraca dan laporan laba-rugi yang sudah di audit dan di terbitkan oleh Bursa Efek Indonesia (BEI)

\section{HASIL DAN PEMBAHASAN}

Pembahasan PT Indosat, Tbk.

\section{Perhitungan analisis Common-size Aset PT Indosat, Tbk}

Jumlah Aset Lancar

Jumlah Aset Tidak Lancar

$$
\begin{array}{r}
2014=\frac{8.590 .976}{53.254 .841} \times 100 \%=16,13 \% \\
2015=\frac{9.918 .677}{55.388 .517} \times 100 \%=17,90 \% \\
2016=\frac{8.073 .481}{50.838 .704} \times 100 \%=15,88
\end{array}
$$

$$
\begin{gathered}
2014=\frac{44.678 .721}{53.254 .841} \times 100 \%=83,90 \% \\
2015=\frac{45.469 .840}{55.388 .517} \times 100 \%=82,09 \% \\
2016=\frac{42.765 .223}{50.838 .704} \times 100 \%=84,12 \%
\end{gathered}
$$

Tabel 2 : PT INDOSAT, TBK.

\section{LAPORAN POSISI KEUANGAN perkomponen}

COMMON-SIZE Tahun 2014 - 2016

\begin{tabular}{|l|c|c|c|}
\hline & $\begin{array}{c}\mathbf{2 0 1 4} \\
\mathbf{\%}\end{array}$ & $\begin{array}{c}\mathbf{2 0 1 5} \\
\mathbf{\%}\end{array}$ & $\begin{array}{c}\mathbf{2 0 1 6} \\
\mathbf{\%}\end{array}$ \\
\hline ASET LANCAR & & & \\
\hline Jumlah aset lancar & 16,13 & 17,90 & 15,88 \\
\hline ASET TIDAK LANCAR & & & \\
\hline Jumlah aset tidak lancar & 83,90 & 82,09 & 84,12 \\
\hline
\end{tabular}

Sumber : Data diolah peneliti (2018)

Persentase aset lancar terhadap total aset cenderung naik, pada tahun 2014 sebesar 16,13\% dan tahun 2015 sebesar 17,90\% sedangkan tahun 2016 mengalami 
turun sebesar $15,88 \%$. Kondisi ini dikarenakan adanya penurunan aset tidak lancar pada tahun 2014 sampai tahun 2015. Kondisi ini menunjukkan kemampuan perusahaan untuk memenuhi kewajiban jangka pendeknya dari aset lancar baik, sedangkan pada tahun 2016 menurun (Kasmir, 2016).

Persentase aset tidak lancar terhadap total aset cenderung naik. Dari tahun 2014 sebesar 83,90\%, tahun 2015 sebesar 82,09\%, tahun 2016 sebesar 84,12\%. Hal ini disebabkan perusahaan sedang melakukan investasi yang cukup besar pada tahun 2016 (Kasmir, 2016).

\section{Perhitungan analisis Common-size " Pasiva “ PT Indosat, Tbk}

Jumlah liabilitas jangka pendek

$$
\begin{aligned}
2014 & =\frac{21.147 .814}{53.254 .841} \times 100 \%=39,71 \% \\
2015 & =\frac{20.052 .600}{55.388 .517} \times 100 \%=36,20 \% \\
2016 & =\frac{19.086 .592}{50.838 .704} \times 100 \%=37,54 \%
\end{aligned}
$$

Jumlah liabilitas jangka panjang

$$
\begin{aligned}
2014 & =\frac{17.823 .328}{53.254 .841} \times 100 \%=33,47 \% \\
2015 & =\frac{22.072 .076}{55.388 .517} \times 100 \%=39,85 \% \\
2016 & =\frac{17.574 .993}{50.838 .704} \times 100 \%=34,57 \%
\end{aligned}
$$

Jumlah Liabilitas

$$
\begin{aligned}
2014 & =\frac{38.971 .142}{53.254 .841} \times 100 \%=73,18 \% \\
2015 & =\frac{42.124 .676}{55.388 .517} \times 100 \%=79,66 \% \\
2016 & =\frac{36.661 .585}{50.838 .704} \times 100 \%=72,11 \%
\end{aligned}
$$

Jumlah Ekuitas

$$
\begin{aligned}
2014 & =\frac{14.298 .555}{53.254 .841} \times 100 \%=26,85 \% \\
2015 & =\frac{13.263 .841}{55.388 .517} \times 100 \%=23,95 \% \\
2016 & =\frac{14.177 .119}{50.838 .704} \times 100 \%=27,89 \%
\end{aligned}
$$


Tabel 3 : PT INDOSAT, TBK.

LAPORAN POSISI KEUANGAN perkomponen

COMMON-SIZE Tahun 2014 - 2016

\begin{tabular}{|l|c|c|c|}
\hline & $\begin{array}{c}\mathbf{2 0 1 4} \\
\mathbf{\%}\end{array}$ & $\begin{array}{c}\mathbf{2 0 1 5} \\
\mathbf{\%}\end{array}$ & $\begin{array}{c}\mathbf{2 0 1 6} \\
\mathbf{\%}\end{array}$ \\
\hline LIABILITAS JANGKA PENDEK & & & \\
\hline Jumlah liabilitas jangka pendek & 39,71 & 36,20 & 37,54 \\
\hline LIABILITAS JANGKA PANJANG & & & \\
\hline Jumlah liabilitas jangka panjang & 33,47 & 39,85 & 34,57 \\
\hline JUMLAH LIABILITAS & 73,18 & 79,66 & 72,11 \\
\hline EKUITAS & & & \\
\hline JUMLAH EKUITAS & 26,85 & 23,95 & 27,89 \\
\hline
\end{tabular}

Sumber : Data diolah peneliti (2018)

Persentase kewajiban lancar terhadap total pasiva cenderung turun dari tahun 2014 sebesar 39,71\%, tahun 2015 sebesar 36,20\%. Hal ini menunjukan semakin turun persentase berarti semakin kecil resiko yang dihadapi perusahaan pada tahun 2014 sampai tahun 2015, sedangkan tahun 2016 naik sebesar 37,54\% (Jumingan, 2014).

Persentase kewajiban tidak lancar terhadap total pasiva cenderung naik, dari tahun 2014 sebesar 33,47\%, tahun 2015 sebesar 39,85\%. Namun tahun 2016 turun menjadi 34,57\%, dengan penurunan akan sulit memenuhi pembiayaan aktivitas perusahaan yang mana produktivitas tidak akan meningkat serta perusahaan tidak akan berkembang bisnisnya (Jumingan, 2014). Dari hal ini penemuan teori baru bahwa secara otomatis laba tidak akan meningkat, dengan begitu perlu adanya penambahan kewajiban lancer (Wiagustini, 2014). Persentase Ekuitas terhadap total pasiva cenderung turun dari tahun 2014 sebesar 26,85\%, tahun 2015 sebesar 23,95\%, dan tahun 2016 sebesar 27,89\%. Pada tahun 2014 sampai tahun 2016 persentase dibawah 50\%. Ini berarti perusahaan dalam mengalokasikan dana untuk aset sebagian besar berasal dari utang. Lebih besarnya sumber modal dari utang dibandingkan dengan modal sendiri akan menimbulkan beban berat bagi perusahaan dan rendahnya margin of safety bagi para kreditur (Jumingan, 2014). 
Perhitungan analisis Common-size “ Laporan Laba-Rugi “ PT Indosat, Tbk :

LAB/RUGI SEBELUM PAJAK PENGHASILAN

LABA/ RUGI TAHUN BERJALAN

$$
\begin{gathered}
2014=\frac{1.962 .032}{24.085 .101} \times 100 \%=8,15 \% \\
2015=\frac{1.785 .835}{26.768 .528} \times 100 \%=6,67 \% \\
2016=\frac{1.795 .263}{29.184 .624} \times 100 \%=6,15 \%
\end{gathered}
$$

$$
\begin{aligned}
2014 & =\frac{1.878 .229}{24.085 .101} \times 100 \%=7,80 \% \\
2015 & =\frac{1.163 .478}{26.768 .528} \times 100 \%=4,35 \% \\
2016 & =\frac{1.275 .655}{29.184 .624} \times 100 \%=4,37 \%
\end{aligned}
$$

Tabel 4 : PT INDOSAT, TBK.

LAPORAN LABA-RUGI

COMMON-SIZE Tahun 2014 - 2016

\begin{tabular}{|l|c|c|c|}
\hline & $\begin{array}{c}\mathbf{2 0 1 4} \\
\mathbf{\%}\end{array}$ & $\begin{array}{c}\mathbf{2 0 1 5} \\
\mathbf{\%}\end{array}$ & $\begin{array}{c}\mathbf{2 0 1 6} \\
\mathbf{\%}\end{array}$ \\
\hline PENDAPATAN & 100 & 100 & 100 \\
\hline $\begin{array}{l}\text { LABA/RUGI SEBELUMPAJAK } \\
\text { PENGHASILAN }\end{array}$ & 8,15 & 6,67 & 6,15 \\
\hline LABA/RUGI TAHUN BERJALAN & 7,80 & 4,35 & 4,37 \\
\hline
\end{tabular}

Sumber : Data diolah peneliti (2018)

Persentase laba kotor terhadap pendapatan cenderung menurun dari tahun 2014 sebesar 8,15\%, tahun 2015 sebesar 6,67\%, tahun 2016 sebesar 6,15\%. Begitu pula dengan laba bersih terhadap pendapatan cenderung menurun dari tahun 2014 sebesar 7,80\%, tahun 2015 sebesar 4,35\%, tahun 2016 sebesar 4,37\%. Kondisi ini menunjukkan kemampuan perusahaan dalam menghasilkan laba bersih berdasarkan tingkat penjualannya semakin buruk (Wiagustini, 2014).

Pembahasan PT Telekomunikasi, Tbk.

Perhitungan analisis Common-size Aset PT Telekomunikasi, Tbk :

Jumlah aset lancar

$$
\begin{aligned}
& 2014=\frac{33.762}{140.895} \times 100 \%=23,96 \% \\
& 2015=\frac{47.912}{166.173} \times 100 \%=28,83 \%
\end{aligned}
$$




$$
2016=\frac{47.701}{179.611} \times 100 \%=26,58 \%
$$

. Jumlah aset tidak lancar

$$
\begin{aligned}
2014 & =\frac{107.133}{140.895} \times 100 \%=76,04 \% \\
2015 & =\frac{118.261}{166.173} \times 100 \%=71,17 \% \\
2016 & =\frac{131.910}{179.611} \times 100 \%=73,44 \%
\end{aligned}
$$

Tabel 5 : PT TELEKOMUNIKASI, TBK.

\section{LAPORAN POSISI KEUANGAN perkomponen}

COMMON-SIZE Tahun 2014 - 2016

\begin{tabular}{|l|c|c|c|}
\hline & $\begin{array}{c}\mathbf{2 0 1 4} \\
\mathbf{\%}\end{array}$ & $\begin{array}{c}\mathbf{2 0 1 5} \\
\mathbf{\%}\end{array}$ & $\begin{array}{c}\mathbf{2 0 1 6} \\
\mathbf{\%}\end{array}$ \\
\hline ASET LANCAR & & & \\
\hline Jumlah aset lancar & 23,96 & 28,83 & 26,58 \\
\hline ASET TIDAK LANCAR & - & - & - \\
\hline Jumlah aset tidak lancar & 76,04 & 71,17 & 73,44 \\
\hline
\end{tabular}

Sumber : Data diolah peneliti (2018)

Persentase aset lancar terhadap total aset cenderung naik, pada tahun 2014 sebesar 23,96\% dan tahun 2015 sebesar 28,83\% sedangkan tahun 2016 turun menjadi 26,58\%. Kondisi ini dikarenakan adanya penurunan aset tidak lancar pada tahun 2014 sampai tahun 2015. Kondisi ini menunjukkan kemampuan perusahaan untuk memenuhi kewajiban jangka pendeknya dari aset lancar baik, sedangkan pada tahun 2016 menurun (Kasmir, 2016).

Persentase aset tidak lancar terhadap total aset cenderung naik. Dari tahun 2014 sebesar 76,04\%, tahun 2015 sebesar 71,17\%, tahun 2016 sebesar 73,44\%. Hal ini disebabkan perusahaan sedang melakukan investasi yang cukup besar pada tahun 2016 ( Kasmir, 2016).

\section{Perhitungan analisis Common-size “ Pasiva “ PT Telekomunikasi, Tbk:}

Jumlah liabilitas jangka pendek

$$
\begin{aligned}
2014 & =\frac{31.786}{140.895} \times 100 \%=22,56 \% \\
2015 & =\frac{35.413}{166.173} \times 100 \%=21,31 \% \\
2016 & =\frac{39.762}{179.611} \times 100 \%=22,14 \%
\end{aligned}
$$


. Jumlah liabilitas jangka panjang

$$
\begin{aligned}
2014 & =\frac{22.984}{140.895} \times 100 \%=16,31 \% \\
2015 & =\frac{37.332}{166.173} \times 100 \%=22,47 \% \\
2016 & =\frac{34.305}{179.611} \times 100 \%=19,10 \%
\end{aligned}
$$

Jumlah Liabilitas

$$
\begin{aligned}
2014 & =\frac{54.770}{140.895} \times 100 \%=38,87 \% \\
2015 & =\frac{72.745}{166.173} \times 100 \%=43,78 \% \\
2016 & =\frac{74.067}{179.611} \times 100 \%=41,24 \%
\end{aligned}
$$

. Jumlah Ekuitas

$$
\begin{aligned}
2014 & =\frac{86.125}{140.895} \times 100 \%=61,13 \% \\
2015 & =\frac{93.428}{166.173} \times 100 \%=56,22 \% \\
2016 & =\frac{105.544}{179.611} \times 100 \%=58,76 \%
\end{aligned}
$$

Tabel 6 : PT TELEKOMUNIKASI, TBK.

\section{LAPORAN POSISI KEUANGAN perkomponen}

COMMON-SIZE Tahun 2014 - 2016

\begin{tabular}{|l|c|c|c|}
\hline & $\mathbf{2 0 1 4}$ & $\mathbf{2 0 1 5}$ & $\mathbf{2 0 1 6}$ \\
\hline LIABILITAS JANGKA PENDEK & $\mathbf{\%}$ & $\mathbf{\%}$ & $\mathbf{\%}$ \\
\hline Jumlah liabilitas jangka pendek & 22,56 & 21,31 & 22,14 \\
\hline LIABILITAS JANGKA PANJANG & & & \\
\hline Jumlah liabilitas jangka panjang & 16,31 & 22,47 & 19,10 \\
\hline JUMLAH LIABILITAS & 38,87 & 43,78 & 41,24 \\
\hline EKUITAS & & & \\
\hline JUMLAH EKUITAS & 61,13 & 56,22 & 58,76 \\
\hline
\end{tabular}

Sumber : Data diolah peneliti (2018) 
Persentase kewajiban lancar terhadap total pasiva cenderung turun dari tahun 2014 sebesar 22,56\%, tahun 2015 sebesar 21,31\%. Hal ini menunjukan semakin turun persentase berarti semakin kecil resiko yang dihadapi perusahaan pada tahun 2014 sampai tahun 2015, sedangkan tahun 2016 naik sebesar 22,14\% (Jumingan, 2014).

Persentase kewajiban tidak lancar terhadap total pasiva cenderung naik, dari tahun 2014 sebesar 16,31\%, tahun 2015 sebesar 22,47\%. Namun tahun 2016 turun sebesar 19,10\%, dengan penurunan akan sulit memenuhi pembiayaan aktivitas perusahaan yang mana produktivitas tidak akan meningkat serta perusahaan tidak akan berkembang bisnisnya (Jumingan, 2014). Dari hal ini penemuan teori baru bahwa secara otomatis laba tidak akan meningkat, dengan begitu perlu adanya penambahan kewajiban lancer (Wiagustini, 2014). Persentase Ekuitas terhadap total pasiva cenderung turun dari tahun 2014 sebesar 61,13\%, tahun 2015 sebesar 56,22\%, dan mengalami kenaikan pada tahun 2016 sebesar 58,76\%. Pada tahun 2014 sampai tahun 2016 persentase diatas $50 \%$. Ini berarti perusahaan dalam mengalokasikan dana untuk aset sebagian besar berasal dari modal sendiri. Lebih besarnya sumber modal dari modal sendiri dibandingkan utang akan meningkatkan margin of safety bagi kreditur dan menguatkan posisi keuangan perusahaan (Jumingan, 2014)

\section{Perhitungan analisis Common-size “ Laporan Laba-Rugi “ PT Telekomunikasi, Tbk}

LABA USAHA

$$
\begin{aligned}
2014 & =\frac{29.377}{89.696} \times 100 \%=32,75 \% \\
2015 & =\frac{32.418}{102.470} \times 100 \%=31,64 \% \\
2016 & =\frac{39.195}{116.333} \times 100 \%=33,69 \%
\end{aligned}
$$

LABA SEBELUM PAJAK PENGHASILAN

$$
\begin{aligned}
2014 & =\frac{28.784}{89.696} \times 100 \%=32,09 \% \\
2015 & =\frac{31.342}{102.470} \times 100 \%=30,59 \% \\
2016 & =\frac{38.189}{116.333} \times 100 \%=32,83 \%
\end{aligned}
$$


.LABA TAHUN BERJALAN

$$
\begin{aligned}
2014 & =\frac{21.446}{89.696} \times 100 \%=23,91 \% \\
2015 & =\frac{23.317}{102.470} \times 100 \%=22,75 \% \\
2016 & =\frac{29.172}{116.333} \times 100 \%=25,08 \%
\end{aligned}
$$

Tabel 7 : PT TELEKOMUNIKASI, TBK.

LAPORAN LABA-RUGI

COMMON-SIZE Tahun 2014 - 2016

\begin{tabular}{|l|c|c|c|}
\hline & $\begin{array}{c}\mathbf{2 0 1 4} \\
\mathbf{\%}\end{array}$ & $\begin{array}{c}\mathbf{2 0 1 5} \\
\mathbf{\%}\end{array}$ & $\begin{array}{c}\mathbf{2 0 1 6} \\
\mathbf{\%}\end{array}$ \\
\hline PENDAPATAN & 100 & 100 & 100 \\
\hline LABA USAHA & 32,75 & 31,64 & 33,69 \\
\hline LABA SEBELUM PAJAK PENGHASILAN & 32,09 & 30,59 & 32,83 \\
\hline LABA TAHUN BERJALAN & 23,91 & 22,75 & 25,08 \\
\hline
\end{tabular}

Sumber : Data diolah peneliti (2018)

Persentase laba kotor terhadap pendapatan cenderung menurun dari tahun 2014 sebesar 32,09\%, tahun 2015 sebesar 30,59\%, tahun 2016 mengalami kenaikan sebesar $32,83 \%$. Begitu pula dengan laba bersih terhadap pendapatan cenderung menurun dari tahun 2014 sebesar 23,91\%, tahun 2015 sebesar 22,75\%, tahun 2016 mengalami kenaikan sebesar 25,08\%. Kondisi ini menunjukkan kemampuan perusahaan dalam menghasilkan laba bersih berdasarkan tingkat penjualannya semakin buruk selama tahun 2014 dan 2015 tetapi pada tahun 2016 perusahaan mampu meningkatkan penjualannya (Wiagustini, 2014).

\section{KESIMPULAN DAN SARAN}

\section{Kesimpulan}

\section{PT Indosat, Tbk.}

Hasil analisis Common-size menunjukkan kondisi keuangan jangka pendek dilihat dari persentase aktiva lancar terhadap total aktiva cenderung turun. Kondisi ini dikarenakan adanya kenaikan aktiva tidak lancar yang cukup tajam dari tahun 20142016. Pada tahun 2014 - 2016 persentase aktiva lancar terhadap total aktiva lebih kecil 
dari utang lancar terhadap total pasiva. Kondisi ini menunjukkan likuiditas perusahaan semakin menurun dan kemampuan perusahaan untuk memenuhi kewajiban jangka pendeknya dari aktiva lancar semakin menurun.

Hasil analisis Common-size menunjukkan kondisi keuangan jangka pendek dilihat dari persentase kewajiban lancar terhadap total pasiva cenderung naik. Kondisi tersebut disebabkan adanya penurunan aset tidak lancar pada tahun 2014 sampai tahun 2015. Kondisi ini menunjukkan kemampuan perusahaan untuk memenuhi kewajiban jangka pendeknya dari aset tidak lancar baik.

Hasil analisis Common-size menunjukkan kondisi keuangan jangka panjang dilihat dari persentase kewajiban tidak lancar terhadap total pasiva cenderung naik. Kondisi tersebut disebabkan perusahaan membutuhkan dana yang cukup besar untuk meningkatkan produktivitasnya dalam penambahan aset lancarnya.

Hasil analisis Common-size menunjukkan kondisi keuangan jangka panjang dilihat dari persentase equitas terhadap total pasiva cenderung turun. Pada tahun 2014 2016 persentase di bawah $50 \%$, berarti Perusahaan dalam mengalokasikan dana untuk aktiva sebagian besar berasal dari utang. Kondisi tersebut menunjukkan jaminan modal untuk membayar utang semakin menurun.

Hasil analisis Common-size menunjukkan kondisi hasil usaha dilihat dari laba rugi memperlihatkan persentase laba bersih terhadap pendapatan cenderung menurun. Kondisi ini menunjukkan perusahaan kurang efektif dalam meningkatkan pendapatan dan belum mampu melakukan efisiensi biaya sehingga persentase laba bersih semakin menurun.

\section{PT Telekomunikasi, Tbk.}

Hasil analisis Common-size menunjukkan kondisi keuangan jangka pendek dilihat dari persentase aktiva lancar terhadap total aktiva cenderung naik. Kondisi ini dikarenakan adanya penurunan aktiva tidak lancar yang cukup tajam dari tahun 2014 2016. Pada tahun 2014 - 2016 persentase aktiva lancar terhadap total aktiva lebih kecil dari utang lancar terhadap total pasiva. Kondisi ini menunjukkan likuiditas perusahaan semakin menurun dan kemampuan perusahaan untuk memenuhi kewajiban jangka pendeknya dari aktiva lancar semakin menurun.

Hasil analisis Common-size menunjukkan kondisi keuangan jangka pendek dilihat dari persentase kewajiban lancar terhadap total pasiva cenderung naik. Kondisi tersebut disebabkan adanya penurunan aset tidak lancar pada tahun 2014 sampai tahun 2015. Kondisi ini menunjukkan kemampuan perusahaan untuk memenuhi kewajiban jangka pendeknya dari aset tidak lancar baik. 
Hasil analisis Common-size menunjukkan kondisi keuangan jangka panjang dilihat dari persentase kewajiban tidak lancar terhadap total pasiva cenderung naik. Kondisi tersebut disebabkan perusahaan membutuhkan dana yang cukup besar untuk meningkatkan produktivitasnya dalam penambahan aset lancarnya.

Hasil analisis Common-size menunjukkan kondisi keuangan jangka panjang dilihat dari persentase equitas terhadap total pasiva cenderung turun. Pada tahun 2014 2016 persentase di atas $50 \%$, berarti Perusahaan dalam mengalokasikan dana untuk aktiva sebagian besar berasal dari modal sendiri. Kondisi tersebut menunjukkan bahwa meningkatkannya margin of safety bagi kreditur dan menguatkan posisi keuangan perusahaan.

Hasil analisis Common-size menunjukkan kondisi hasil usaha dilihat dari laba rugi memperlihatkan persentase laba bersih terhadap pendapatan cenderung menurun. Kondisi ini menunjukkan perusahaan kurang efektif dalam meningkatkan pendapatan dan belum mampu melakukan efisiensi biaya sehingga persentase laba bersih semakin menurun, tetapi pada tahun 2016 perusahaan mampu meningkatkan penjualannya.

\section{Saran}

1. Harus dilakukan evaluasi terhadap seluruh biaya yang dikeluarkan agar perusahaan mampu memenuhi kewajiban-kewajibannya.

2. Melakukan strategi yang lebih efektif dalam pengelolaan anggaran berdasarkan prinsip ekonomi

3. Perlu dilakukannya penelitian selanjutnya dalam rentang waktu bervariasi, agar hasil yang diperoleh lebih maksimal.

\section{DAFTAR PUSTAKA}

Aminah, S. 2016. Analisis Common Size Statement Dan Trend Untuk Menilai Kinerja Keuangan PT.KAI. Volume 5, Nomor 3. Sekolah Tinggi Ilmu Ekonomi Indonesia (STIESIA) Surabaya.

Harahap, Sofyan Syafari. 2008. Analisis Kritis Laporan Keuangan. Jakarta : Penerbit Raja Grafindo Persada.

Hery. 2016. Analisis laporan keuangan. Jakarta : Penerbit PT Gramedia.

Prasetyo, D. Z, A, Zahroh. \& Devi, F. 2007. Pengaruh Keputusan Investasi dan Keputusan Pendanaan Terhadap Nilai Perusahaan ( Studi kasus Perusahaan Sektor Property dan Real Estate yang Terdaftar di BEI Periode Tahun 20092011). Universitas Brawijaya.

Prihastuti, K.Suwena, R \& Sujana,N. 2017. Analisis Kinerja keuangan dengan menggunakan Common-size Pada Perusahaan Otomotif Yang Terdaftar di Bursa Efek Indonesia (BEI) Tahun 2016. Vol: 10 No: 2. Universitas Pendidikan Ganesha Singaraja. 
PSAK PRA 47. 2002. Standart Akuntansi Keuangan. Jakarta : Penerbit Salemba Empat.

Putra, Y. P., \& Laely, N. (2015). Analisis Laporan Keuangan Berdasrkan Rasio Likuiditas, Solvabilitas \& Rentabilitas Untuk Menilai Kinerja Keuangan Pada Koperasi Manunggal Universitas Kadiri. Jurnal Kompilasi Ilmu Ekonomi, 7(1), 89-98.

Sutomo, I. 2014. Analisis Rasio Profitabilitas Untuk Menilai Kinerja Keuangan Pada PT Niagaraya Kreasi Lestari Banjarbaru. Volume 10 Nomor 4. STIE Pancasetia Banjarmasin.

Sudjana. 2006. Tuntunan Penyusunan Karya Ilmiah. Penerbit Sinar Baru.

Sugiyono. 2012. Metode penelitian pendidikan (pendekatan kuantitatif, kualitatif dan $R$ \& D). Bandung : Penerbit Alfabeta.

Sugiyono. Pengertian Populasi Menurut Definisi Para Ahli. www.landasanteori.com/20015/08/pengertan-populasi-menurut-defnisipara.html. 18 Februari 2018 (13.32 WIB).

Sugiyono. Pengertian Sampel Menurut Definisi Para Ahli. www.landasanteori.com/20015/08/pengertan-sampel-menurut-defnisi- para.html. 18 Februari 2018 (13.30 WIB).

Sugiyono. Pengertian Purposive Sampling Menurut Para Ahli. www.pengertianmenurutparaahli.rayendar.blogspot.co.id. 15 Februari 2018 (11.01 WIB).

Vaulia, N. (2017). Pengaruh Spread Suku Bunga, Car, dan NPL Terhadap Penyaluran Kredit UKM Kota Kediri (Studi Pada Perbankan Kota Kediri). Ekonika, 2 No 1, 57-74.

Wirawan. 2001. Cara Mudah memahami Statistik. Jakarta : Penerbit Salemba Empat. 